\title{
The Impact of Implementing SAP System on Human Resource Management: Application to Saudi Electricity Company
}

\author{
Kamel Khoualdi ${ }^{1} \&$ Abdullah Basahel ${ }^{1}$ \\ ${ }^{1}$ Management Information Systems Department, King Abdulaziz University, Jeddah, Saudi Arabia \\ Correspondence: Kamel Khoualdi, Management Information Systems Department, King Abdulaziz University, \\ P.O. Box 80201, Jeddah 21589, Saudi Arabia. Tel: 966-126-952-000. E-mail: kamel_khoualdi@yahoo.com
}

Received: July 29, 2014

Accepted: October 28, $2014 \quad$ Online Published: November 22, 2014

doi:10.5539/ijbm.v9n12p28

URL: http://dx.doi.org/10.5539/ijbm.v9n12p28

\begin{abstract}
This study is aimed at exploring the benefits of using the SAP system to manage the human resource at the Saudi Electricity Company (SECO). After SECO unified power companies across the country, it had an urgent need to standardize its procedures between the business areas in the Kingdom. Therefore, the senior management agreed to start to apply SAP in 2005. The goal of this paper was to reveal the challenges facing the implementation of SAP, identify how to plan the requirements of a human resource information system, and to evaluate the performance of the contractors that implemented the SAP. We used employee feedback to inform our results. More than (90) employees from different locations filled out the evaluation forms. We analyzed the responses using SPSS and concluded there was a cost reduction of $33 \%$ by using SAP.
\end{abstract}

Keywords: SAP, human resource management, Saudi electricity company

\section{Introduction}

\subsection{Background}

After the introduction of the Internet, many job functions changed from manual to automate. Using computers simplified storing and retrieving human resource records. According to Chakraborty (Chakraborty \& Abu Mansor, 2013) and Ruël (Ruël et al., 2011), human resource information systems (HRIS) will aid organizations maintain full and updated databases, which they can retrieve as needed. Many experts say that HRM in any company in Saudi Arabia nowadays encounters challenges such as storing and retrieving data, firing and hiring, blacklists, social security concerns, other records about the ministry of labor, tracking performance, training, and cost figures. Thus, information systems (IS) play a major role in managing human resource, especially in Saudi Arabia.

The main questions were how much SECO benefitted from using the SAP system for human resource and were the employees satisfied with the training they had on the system and with the contractor that executed SAP.

The main goal of this research is:

- To identify the challenges facing HRIS in SECO.

- To identify how to plan the needs of an HRIS.

- To identify the elements to evaluate to choose the contractors for SAP.

- To identify the problems facing the employees using HRIS and their training.

- To identify the benefits gained by applying SAP in SECO from the aspect of improving communications between different departments.

\subsection{Importance of the Problem}

The study will explore the importance of SAP in managing human resource through studying the purposes and uses of HRIS and how to develop and execute them at SECO. The improvements an information system can make in a business make it necessary to ensure the quality of the IS services because it improves the organization's services in general. 


\subsection{Literature Review}

Enterprise Resources Planning (ERP) is a system that integrates the management of information through the management of the flow of data across the entire enterprise (Botta-Genoulaz et al., 2005) (Schlichter \& Kraemmergaard, 2010). Organizations usually buy ERP systems because of the inefficiency of institutional processes. Through automating business processes, enhancing operational efficiency, and easing access to information, the application of an ERP system improves the performance of the organization in its daily operations. Organizations often think about getting ERP when they deal with many complex and overlapping business problems. Most of these organizations expect to receive trade benefits through the implementation of ERP. One of these benefits is achieve the financial goals of the company through productivity gains and efficiency resulting from business process automation. Another is to simplify the management and operations of a large-scale company that has grown organically or through acquisitions. Such a company may involve multiple currencies, offices, or business areas. ERP acquisition can also replace or upgrade an outdated, unwanted or ineffective existing ERP system. This can involve improved information management through the promotion of access to information, reducing duplication of data and improving predictive capabilities.

Many companies have introduced new systems that will help in upgrading and managing their daily business resource and processes and link the sections to each other. All this is possible through a single, comprehensive ERP system. Many companies specialize in building these systems; the most famous such company is SAP, which produced a product that bears its name (SAP). The SAP program began in 1972, developed initially by three German programmers working for IBM. They then resigned and set up their own company, located in Walldorf, Germany. SAP employs approximately 52000 people.

The company has evolved the software until it has become a comprehensive program for all sections of a company, whether the company is small, medium, or large. It is now one of the largest companies that provides practical solutions to businesses (Gargeya \& Brady, 2005). However, systems are expensive and most often purchased by the largest companies. Its main activity is to produce management programs that help enterprises improve their businesses and connect them into one system to ensure its coherence and efficiency without having to use several software systems from different companies.

There are thousands of companies worldwide that are using SAP program. Some examples in Saudi Arabia are SABIC, ARAMCO, Saudi Airlines, and SECO. The applications in SAP are called modules and they are connected together usually but you can buy one module or more separately according to your needs. We emphasized in this research the human resource module in SECO because it is the first module to be implemented and due to its importance. Many researches have discussed human resource information systems. Al-Hudaif (2010) measured the quality of services of information systems in industrial organizations in Riyadh. Nagendra and Deshpande (2014) analyzed the effect of HRIS in the public sector. Ball (2001) reviewed the use and importance of human resource information systems in smaller organizations. Kumar and Parumasur (2013) investigated the impact of the HRIS system on organizational efficiency in South Africa. Troshani et al. (2007) studied the factors that induce the organizational use of human resource information systems in public sector organizations.

\section{Research Methodology}

\subsection{Hypothesis}

The study addressed the following hypotheses:

H0: There will be no differences in the use of human resources information systems.

H1-3: SAP will:

- Reduce the cost and time of human resources.

- Improve communication between the departments of human resources and unify regulations.

- Increase the satisfaction of consumer and customers.

H4-5 Employees will:

- Be satisfied of with the SAP training.

- Be satisfied with the SAP executive contractor.

2.2 Sampling Procedures

Most of the questionnaires were sent by email to different sites in SECO and only included fully completed questionnaires. The questionnaire used a Likert scale from 1 to 5 ( 1 as "strongly disapprove" and 5 as "strongly 
approve"). The values of the Cronbach's alpha coefficient for the stability of the internal consistency of all the axes and the tool as a whole ranged from 0.70 to 0.92 , and the value of the Cronbach's alpha coefficient for the tool as a whole was 0.93 . Therefore, the search tool has high internal stability and well positioned to measure the phenomenon. It is thus possible to apply all the methods of statistical analysis to the results.

The questionnaire had the following sections:

- General information about the knowledge of employees about SAP.

- The cost and time variables.

- The unification of the system and improvement of communications between departments.

- The increase of internal and external customer satisfaction.

- Training provided to employees about the system.

- $\quad$ Trust in the SAP contractor.

We measured the success of the project by the compliance with the goals of each sector. For human resources, these included the following:

- To achieve smooth procedures, improved services and rapid response of the staff by eliminating manual work and paper forms.

- To enhance the potential of decision making by providing managers with the right information at the right time.

- To reduce the cost of human resources services.

\section{Results and Discussion}

Using the Pearson correlation factor between the degree of each factor and the total degree of the factors, the result showed the relations varied between medium positive $(0.58)$ relations to very high positive $(0.82)$ relations. This indicates the questionnaire is sufficient to measure the hypotheses.

We analyzed the data using the SPSS program and these measures:

- $\quad$ Frequencies and percentages.

- Cronbach's alpha.

- Pearson's Coefficient of Correlation

- $\quad$ Arithmetic mean and standard deviation

- $\quad$ One-sample T-Test.

We categorized the characteristics of the members according to age, educational level, and years of experience as follows:

- $\quad 21.7 \%$ of the research sample were between $26-30$ years old, $21.7 \%$ were $36-40,19.6 \%$ were $31-35,14.1 \%$ were $41-45,8.7 \%$ were $46-50,3.3 \%$ were $51-55$, and $2.2 \%$ were between $56-60$ years old;

- $\quad 54.3 \%$ had bachelor degrees, $16.3 \%$ had higher degrees, $14.1 \%$ went to technical school, $9.8 \%$ had high school degrees, and $5.4 \%$ had less than a high school education.

- $\quad 27.2 \%$ of the sample had 6-10 years of service, $25 \%$ had $11-15$ years of service, $21.7 \%$ had less than 5 years of service, $13.2 \%$ had $16-20$ years of service, $7.4 \%$ had 21 to 25 years of service, and $5.5 \%$ had 26 to 30 years of service. These percentages show that $77 \%$ of the sample had less than 20 years of service, while $13 \%$ of them had more than 20 years.

The main factors in the questionnaires provided the results in Table 1. 
Table 1. Main factors in the questionnaires

\begin{tabular}{lccc}
\hline Variable & Arithmetic mean & Standard Deviation & Rule \\
\hline Reduce Cost & 3.37 & 0.553 & Neutral \\
Reduce Time & 3.44 & 0.381 & Agree \\
Improve Communications & 3.71 & 0.383 & Agree \\
Customer Satisfaction & 3.36 & 0.247 & Neutral \\
Training & 3.16 & 0.226 & Neutral \\
Confidence in contractor & 3.04 & 0.115 & Neutral \\
\hline
\end{tabular}

To check the first hypothesis, we used the T-Test; the results are shown in Table 2.

Table 2. Results for the first hypothesis

\begin{tabular}{lcccc}
\hline Variable & Average score & Standard Deviation & Degrees of Freedom & T-Test Value \\
\hline Cost & 13.47 & 3.065 & 91 & 4.592 \\
Time & 13.77 & 4.098 & 91 & 4.147 \\
\hline
\end{tabular}

To check the second hypothesis, we used the T-Test; the results are shown in Table 3.

Table 3. Results for the second hypothesis

\begin{tabular}{lcccc}
\hline Variable & Average score & Standard Deviation & Degrees of Freedom & T-Test Value \\
\hline Improve & 14.84 & 2.992 & 91 & 9.095 \\
Communications & & & & \\
\hline
\end{tabular}

According to the responses of the members of the research sample, the use of HRIS system led to improved communication and standardization.

To check the third hypothesis, we used the T-Test; the results are shown in Table 4.

Table 4. Results for the third hypothesis

\begin{tabular}{lcccc}
\hline Variable & Average score & Standard Deviation & Degrees of Freedom & T-Test Value \\
\hline $\begin{array}{l}\text { Increase customer } \\
\text { satisfaction }\end{array}$ & 13.42 & 3.926 & 91 & 3.479 \\
\hline
\end{tabular}

According to the responses of the members of the research sample, the use of HRIS system led to increased customer satisfaction.

To check the fourth hypothesis, we used the T-Test; the results are shown in Table 5.

Table 5. Results for the fourth hypothesis

\begin{tabular}{lcccc}
\hline Variable & Average score & Standard Deviation & Degrees of Freedom & T-Test Value \\
\hline Training employees & 12.65 & 4.001 & 91 & 1.563 \\
\hline
\end{tabular}

According to the responses of the members of the research sample, the employees are not satisfied with the training.

To check the last hypothesis, we used the T-Test; the results are shown in Table 6.

Table 6. Results for the fifth hypothesis

\begin{tabular}{lcccc}
\hline Variable & Average score & Standard Deviation & Degrees of Freedom & T-Test Value \\
\hline $\begin{array}{l}\text { Satisfaction about } \\
\text { contractor }\end{array}$ & 12.15 & 3.736 & 91 & 0.391 \\
\hline
\end{tabular}


According to the responses of the members of the research sample, the employees are not satisfied with the contractor.

It was difficult to measure the benefits of using the SAP application at SECO, because there have not been any studies of this type and SECO may need at least five years to measure actual results. But, we got the following information:

- For the company as a whole, the number of employees was reduced from more than 31,000 employees to 27,000 employees in the year 2009 through normal retirement and early resettlement of some employee functions.

- Due to expansion, the company has increased the number of employees to more than 28,000 staff, most of them graduates of colleges and universities.

- The company plans to reduction the number of employees to reduce costs, but this is not linked directly to the SAP regime and involves a number of factors.

We have included the results for the Western Region of SECO in Table 7.

Table 7. Results for the western region

\begin{tabular}{|c|c|c|c|c|}
\hline Variable & Before SAP & After SAP & Difference & Notes \\
\hline Cost of printing & $735 \mathrm{k} / \mathrm{month}$ & $487 \mathrm{k} / \mathrm{month}$ & $-33.7 \%$ & $\begin{array}{l}\text { Partially because of } \\
\text { the use of central } \\
\text { printers }\end{array}$ \\
\hline Number of employees & 195 & 190 & $-2.56 \%$ & $\begin{array}{l}\text { Mostly reduced by } \\
\text { retirement }\end{array}$ \\
\hline $\begin{array}{l}\text { Cost of data input and } \\
\text { storage }\end{array}$ & \multicolumn{4}{|c|}{$\begin{array}{l}\text { No actual study about the cost, but the main goal is central storage in few servers to make maintenance } \\
\text { easier }\end{array}$} \\
\hline Cost of employment & \multicolumn{4}{|c|}{ New employees usually cost less and are more enthusiastic; the savings are about $15 \%$. } \\
\hline
\end{tabular}

For the time factor, the standardization of procedures and the use of centralized data storage that makes retrieving data faster led to decreased time used to perform human resources procedures. Table 8 provides examples of some of these reductions.

Table 8. Examples of some benefits of using SAP

\begin{tabular}{lccc}
\hline Variable & Before SAP & After SAP & Notes \\
\hline $\begin{array}{l}\text { Data input time } \\
\text { (Approving an internal } \\
\text { course) }\end{array}$ & $\begin{array}{l}\text { 1-3 days according to the } \\
\text { location of the employee }\end{array}$ & 1 hour to 1 day & $\begin{array}{c}\text { Some employees work in remote sites } \\
\text { such as power plants that require faxing } \\
\text { papers, which takes time. }\end{array}$ \\
& $\begin{array}{c}\text { Employee must be free to get } \\
\text { training }\end{array}$ & Online courses & $\begin{array}{c}\text { Linking the (iLearn) system with SAP } \\
\text { encourages employees to attend } \\
\text { courses. }\end{array}$ \\
\hline
\end{tabular}

One of the main goals for deploying SAP was to improve communications between the HR departments and to unify systems across the company. Unifying the systems will lead to restructuring the organizational chart by substituting the geographical departments with a central department. It will also lead to improving the time spent on paperwork by improving the procedures.

SECO has undertaken no study to measure the improvement in communications. SAP reduced the time consumed to move the reports from different business areas. For example, a medical examination of a new employee was usually sent by regular mail from Jeddah to Riyadh and could take 1-2 days, but now it can be done automatically through the SAP.

The company has a quality and continuous improvement team. This team conducted as study on customer satisfaction in 2010 . They found a $35 \%$ increase in customer satisfaction with procedures such as registering a newborn, and internal/external courses. 


\section{Conclusion}

Using SAP accomplished the following:

- $\quad$ Reduced paper work, cost, and printers by $33 \%$.

- $\quad$ Decreased the need to hire by $2.5 \%$.

- $\quad$ Provided an easier and faster way of dealing with data, changing transfers from 1-3 days to merely hours.

- Standardized procedures company-wide.

- Increased work output due to better work procedures.

- Speeded transactions.

- Increasing customer satisfaction.

- $\quad$ Added a unified database, making it is easier for employees to move between different sectors.

However, the implementation has also had the following problems:

- $\quad$ The employees are not satisfied with the training on SAP.

- There is a gap between the high-tech trainers and the low-tech trainees that needs to be filled.

- The contractors should be more involved with the employees.

The staff requires more training on the use of SAP and information technology in general. The contractor must provide trainers that can communicate effectively across the knowledge gap with trainees. The company can also try to reduce this gap by attracting new employees with high degrees in technical areas, because they understand IT systems; SECO can also reduce the number of elderly employees through early retirement. SECO can also have the contractor offer some simple technical sessions for the staff to try to improve the relationship with them and increase their understanding of the SAP system.

The SAP system was applied to HR, financial resources, and transportation; there are still stages to come, so SECO should take advantage of these departments' expertise and learn from their past problems. This requires some internal research to identify results. For example, the company did not measure the increases in output after deploying SAP, and should do so in the next year. The company can also seek external sources of SAP information and experience through seminars with SABIC and ARAMCO to exchange knowledge.

The work done in this research can be extended in the following directions:

- Horizontally, to cover more companies in Saudi Arabia.

- To include more factors that may affect human resources.

- To explore the relations with the contractors extensively

- To examine the full implications of SAP on all the modules implemented in SECO.

\section{References}

Al-Hudhaif, S. A. (2010). Measuring quality of information system services in manufacturing organizations in Riyadh. Journal of King Abdulaziz University: Economy \& Administration, 24(1), 151-171. http://dx.doi.rog/10.4197/Eco.24-1.4

Ball, K. S. (2001). The use of human resource information systems: a survey. Personal Review, 30(6), 677-693. http://dx.doi.rog/10.1108/EUM0000000005979

Botta-Genoulaz, V., Millet, P. A., Grabot, B. (2005). A survey on the recent research literature on ERP systems. Computers in Industry, 56(6), 510-522. http://dx.doi.rog/10.1016/j.compind.2005.02.004

Chakraborty, A. R., \& Abu Mansor, N. N. (2013). Adoption of human resource information system: A theoretical analysis. Procedia-Social and Behavioral Sciences, 75, 473-478. http://dx.doi.rog/10.1016/j.sbspro.2013.04.051

Gargeya, V. B., \& Brady, C. (2005). Success and failure factors of adopting SAP in ERP system implementation. Business Process Management Journal, 11(5), 501-516. http://dx.doi.rog/10.1108/14637150510619858

Kumar, N. A., \& Parumasur, S. B. (2013). Managerial perception of the impact of HRIS on organizational efficiency. Journal of Economics and Behavioral Studies, 5(12), 861-875.

Nagendra, A., \& Deshpande, M. (2014). Human resource information systems (HRIS) in HR planning and development in mid and large sized organizations. Procedia - Social and Behavioral Sciences, 133, 61-67. 
http://dx.doi.rog/10.1016/j.sbspro.2014.04.169

Ruël, H., Magalhães, R., Charles, C., \& Chiemeke, C. C. (2011). Chapter 2 Human Resource Information Systems: An Integrated Research Agenda. In Tanya Bondarouk, Huub Ruël, Jan Kees Looise (Eds.), Electronic HRM in Theory and Practice (Advanced Series in Management, Volume 8) Emerald Group Publishing Limited ( pp. 21-39). http://dx.doi.rog/10.1108/S1877-6361(2011)0000008006

Schlichter, B. R., \& Kraemmergaard, P. (2010). A comprehensive literature review of the ERP research field over a decade. Journal of Enterprise Information Management, 23(4), 486-520. http://dx.doi.rog/10.1108/17410391011061780

Troshani, I., Jerram, C., \& Hill, S. R. (2011). Exploring the public sector adoption of HRIS. Industrial Management \& Data Systems, 111(3), 470-488. http://dx.doi.rog/10.1108/02635571111118314

\section{Copyrights}

Copyright for this article is retained by the author(s), with first publication rights granted to the journal.

This is an open-access article distributed under the terms and conditions of the Creative Commons Attribution license (http://creativecommons.org/licenses/by/3.0/). 